Newfoundland and Labrador Studies

\title{
Missionary August Freitag on Music among the Inuit of Labrador in 1844
}

\section{Hans Rollmann et Tom Gordon}

Volume 33, numéro 1, 2018

URI : https://id.erudit.org/iderudit/1055872ar

DOI : https://doi.org/10.7202/1055872ar

Aller au sommaire du numéro

\section{Éditeur(s)}

Faculty of Arts, Memorial University

ISSN

1719-1726 (imprimé)

1715-1430 (numérique)

Découvrir la revue

Citer cet article

Rollmann, H. \& Gordon, T. (2018). Missionary August Freitag on Music among the Inuit of Labrador in 1844. Newfoundland and Labrador Studies, 33(1).

https://doi.org/10.7202/1055872ar d'utilisation que vous pouvez consulter en ligne.

https://apropos.erudit.org/fr/usagers/politique-dutilisation/ 


\title{
Missionary August Freitag on Music among the Inuit of Labrador in 1844
}

\author{
Introduced and Translated from German by \\ Hans Rollmann and Tom Gordon
}

In 1844, August Freitag, a Moravian missionary and trade-brother in Okak, wrote an extended letter to his family that described his work in Okak, Labrador. Freitag, born on 10 March 1807 in Livonia as the child of Moravian church workers, was a cabinetmaker by trade. He arrived in Hebron, Labrador, in 1831 to help with the building of the new settlement. During a furlough in Europe, in May of 1840 Freitag married Sophie Sparmeier (1812-1889), the daughter of Moravian missionaries to St. Thomas in the Caribbean and a trained teacher. After serving in Hebron and Okak, in 1850 he became superintendent of the Labrador mission. Freitag died on his return journey from Labrador on 18 September 1867 and was buried in London. ${ }^{1}$ A portion of his 1844 letter provides insights into the use of European music by Inuit and is presented here as a document, prefaced by the necessary context.

\section{Music at Okak}

Okak, the most northerly missionary settlement in the eighteenth century, participated in the Moravian musical culture since its establishment in 1776. Regular schooling commenced in 1780 with hymn 
singing and memorization of verses as part of the religiously flavoured school curriculum. ${ }^{2}$ Also in church services, singing was a regular feature, first based on a musical manuscript of 100 hymns, ${ }^{3}$ and since 1809 from a printed hymnal, titled TUKSIARUTSIT, / ATTOREKSET / ILLAGEKKTUNNUT / LABRADOREMETUNNUT [Hymns for use in the Labrador congregations]. ${ }^{4}$ Already in 1793, two unmarried women in Nain took great pleasure in reading the unprinted hymns. ${ }^{5}$ Without prompting by missionaries, Inuit singing quickly became a much-liked feature of morning and evening devotionals, both in Okak and on hunting trips in their tents. ${ }^{6}$ As children learned musical verses by heart, the religious effects were noted favourably by the Okak missionaries. "One day," the missionaries observed, "by singing a verse, there arose such an emotion of heart among them, that all melted into tears, and, at last, without any direction, they, of themselves fell on their knees." When the first hymnbook had been printed, the Okak missionaries thanked the missionary society profusely and hoped "that as many of the Esquimaux in the three settlements have already learnt to read, the use of it will be attended with much blessing, and their growth in grace will be furthered thereby." ${ }^{8}$ In 1824, the second, significantly enlarged edition of the hymnbook appeared and was distributed to all those who could read. ${ }^{9}$ In August 1831, the congregation in Okak took "great delight in singing and learning hymns, which assists to enliven our public worship." ${ }^{10}$

Coincident with the arrival of the expanded hymnal, which invigorated congregational singing, another key element of Moravian musical practice was introduced to the Inuit. While the missionaries had been singing anthems together in family worship from their earliest days in Labrador, it was in 1824 that Benjamin Kohlmeister (1756-1844) observed that "[s]ome of the Missionaries have even succeeded in teaching them [the Inuit] to sing short and easy anthems, in three or four parts, by which, on particular occasions, the worship of the congregation is much enlivened."11 The practice must have spread rapidly to all three mission settlements, since Johann Peter Christian Stock (1782-1868) reports four years later from Hopedale: "You will 
be glad to hear, that our Esquimaux retain their love, and cultivate their talent, for music. They play and sing anthems on festival days, and on other occasions." ${ }^{12}$ The extant music manuscript collections from the three original mission stations substantiate the practice with watermarked anthem manuscripts, with Inuktitut texts dating from 1814 (Nain), 1817 (Hopedale), and 1821 (Okak). As Freitag observes, the singing of anthems (or "choir pieces" as they were called in Labrador) was a source of particular satisfaction to the Inuit musicians, despite the challenges of performing music that was rhythmically far more complex than the hymns.

Inuit musicians also took equal delight and showed a great interest in the European instruments that the Moravians introduced. By the early 1820s, Inuit violinists and cellists were accompanying both congregational hymn-singing and choir pieces in Okak and elsewhere. ${ }^{13}$ Instruction on violin and cello, as well as other instruments, was among the duties assumed by the missionaries. Johann Ludwig Morhardt (1782-1854) writes from Hopedale in 1826, "Being appointed both school-master and music-director, (as there is no better), I have enough to do, both with my pen and my schools, but it is a pleasure to me to serve the youth. I wish we had more violins, and a violincello. As likewise a larger assortment of strings; for I perceive, that it is well worth the while to teach the Esquimaux music, and our labour is not in vain. ${ }^{14}$ In addition to string instruments and organ, the Inuit were enthusiastic about learning to play winds and brass. In a thank-you letter from Okak of September 1836, mention is made about "the clarinet presented to our choir by some young friends in London," which was received by choir members with great delight. ${ }^{15} \mathrm{~A}$ clarinet had been in use in Nain by missionaries since 1821, and in 1835, Markus, a principal performer in the Nain choir, preferred this instrument over playing the violin. ${ }^{16}$ The following year, Nain already had two clarinet players, while the previously mentioned Markus and another Inuk, who also played the violincello, had taken up organ playing during Sunday services. ${ }^{17}$ In 1837, Hopedale regretted not having a proper clarinet. "The only one we possess," the Brethren wrote on 27 July 1837, "has been 
strangely constructed; the Eskimo who plays it having himself made the mouth-piece and upper joint, and the two lower being fragments of different instruments." 18 The request of the Hopedale brethren was heard by Superintendent Lundberg in Nain, who sent the Nain clarinet to Hopedale, thus leaving Nain in need of another. ${ }^{19}$

The first organ arrived on the coast in 1824, a gift to the mission station in Nain from the congregation in Herrnhut. A source of wonderment, Inuit travelled from Hopedale and Okak to hear it, as Ludwig Morhardt remarked a few years later: "When visitors from the other congregations at Okkak [sic] and Hopedale attend our services, they are much struck with the effect of the organ, and loudly testify their gratification." Morhardt added that one Inuk expressed himself as follows: "How happy I feel; I am reminded, by what I have heard, of Jesus and of the company of the saved, who surround His throne, and sing His praises. Those are indeed delightful notes, which I shall not soon forget." ${ }^{20}$ Inuit musicians quickly mastered accompanying congregational singing. In August of 1837, we learn that besides Brother Christian Benedict Henn (1780-1845), there was in Okak "an Eskimo brother, who is able to play most of the hymn-tunes in use among us on the organ, and gladly assists in the services of the Church." 1 This brother was presumably Jacobus, who is mentioned by August Freitag in the excerpt below.

Globally, the missionaries found much to admire in the Inuit aptitude and embrace of the music traditions they introduced. Writing in 1830, Morhardt observed, "The singing, both of our little choir, and of the congregation, is very pleasing; and our people evidently take great delight in this enlivening portion of the Christian worship. Their predilection for extreme simplicity of accompaniment is remarkable, and their example in this particular is not unworthy the attention of their more civilized Brethren in Europe."22 This "predilection for simplicity" was especially pleasing to the missionaries, for whom the music was but a vehicle for the spiritual content of the hymns and anthems. In many of their European congregations, the leadership of professional musicians in choirs had led to a practice that approached 
concert standards. The music became a distraction from devotion, distant from the ideal of "simple and artless accompaniment"23 to worship as advocated by Moravian church leaders. In 1835 in Labrador, the missionaries noted with satisfaction, "though their execution is far from being of a masterly kind, it is such as might put to shame the attempts of many a country choir in civilised Europe." ${ }^{24}$

As we approach the early 1840s, the period described in Freitag's manuscript, the congregation at Okak had progressed significantly in their musical taste and performance. "You will be pleased to hear that music is at present flourishing among us," wrote Brother Johann Friedrich Martin (1804-1854). "Our congregation takes great delight in psalmody, - and there are few of our hymn-tunes, even of the more difficult ones, that they do not sing with facility and correctness. Our company of violin-players is complete, and we have two clarinets, by the help of which the performance of chorales and anthems at our festive and liturgical services is rendered more complete." ${ }^{25}$

Freitag's snapshot of music in Okak in 1844 captures all of these currents. The deep attachment the Inuit show both to singing and to accompanying on instruments is evident throughout. So, too, is their inventiveness in the construction and mastery of musical instruments. The sweet quality of their voices and trueness of their singing, both remarked on by Freitag, are evidence of the degree to which their musicianship was more aural than literate. The Inuit quickly learned hymns "by ear" with ease, but their performances of anthems could quickly devolve into "similar sounding garble" because of the complexity of reading the rhythms. In the end the simplicity of the fervent singing and accompaniment on instruments heightened the devotional quality of life in the Moravian missions, striking a resonance with Moravian ideals for the service of music in worship.

\section{Document}

[Brother August Freitag on Music among the Inuit of Labrador in 1844 (English translation):] 
They love music and singing very much, indeed also have - for me, often admirable - talent for it. Their voices may not be exceptional, but their ear for music is exceptional by which they easily learn all the melodies in their hymn books from each other with little guidance.

During work and rest, one often hears the girls in particular begin singing songs; and many are singing a truly correct second voice. They often crowd in on us very forcefully to hear my Sophie play on the keyboard ${ }^{26}$ and, where possible, hear her sing to it, where they could remain for hours. ${ }^{27}$

Not a few know how to play string instruments as well as clarinet and flute, likewise without much instruction, since generally the Eskimo is on the whole much more practical than the European, and what he wants to learn, he learns quickly, but for what he has no interest, he never learns. I have been told: a Hopedale Eskimo who never played any music liked the first oboe he heard so much that he did not stop until he had made himself one from local spruce with poor tools, and had also taught himself to play it, indeed so well that he was later able to accompany the singing in church with it. Also, several people made themselves violins, ${ }^{28}$ strung with seal gut, and the bow stretched with women's hair. They have, of course — as one can imagine - a poor sound, but sound nevertheless.

Hymn singing in church on Sunday and during Friday's liturgies is accompanied in the winter by a violin choir and 1 or 2 clarinets or flutes. In the other meetings - except in Hopedale, where they do not have any - a small organ is played, which here [in Okak], an old violin player in his 50s - Jacob - has learned to play fairly well without any guidance. ${ }^{29}$ False notes (for which the very out-of-tune organ is mainly responsible) are, of course, so many, that a German congregation would lose all devotion and composure, but the Eskimo is not in the least bothered.

They have less of a natural disposition for rhythm ${ }^{30}$ during the performance of easy anthems, ${ }^{31}$ of which they make much. Left alone to themselves, as sometimes happens, it will turn, of course, only into a similar-sounding garble, with which they can offend even a not very 
trained musical ear. But as soon as there is a brother who can instruct them, they learn quickly, and I have sometimes been edified by it, even though their choral singing can by far not be compared with that in our [European] congregations, which is already obvious since the choir consists only of girls who sing in the first voice. ${ }^{32}$ Only in Hopedale has Brother Glitsch made an attempt with four-part harmony. ${ }^{33}$ Bass voices are a great rarity. I have encountered only one, but also a very strong one that by further training one would not be ashamed to listen to. It is a local simple man, who especially nicely enlivens the choral singing of the liturgies.

\section{Notes}

1 "Dienerblätter" [service records] for Carl Traugott August Freitag and Sophia Sparmeier, Unity Archives, Herrnhut, Saxony, Germany (UAH); see also "Lebenslauf des am 18. September 1867 in London selig entschlafenen verheiratheten Bruders Carl Traugott August Freitag," Nachrichten aus der Brüder-Gemeine 1864, no. 4: 337-408.

2 See the letters from Okak, dated 9 Aug. 1796, 7 Aug. 1797, and 5 Sept. 1800 in Periodical Accounts 2 (1797-1800): 55, 123, 467. See Hans Rollmann, "Moravian Education in Labrador: A Legacy of Literacy," in Gerald Galway and David Dibbon, eds., Conference Proceedings: Symposium 2008: Post-Confederation Education Reform — From Rhetoric to Reality (St. John's: Faculty of Education, Memorial University of Newfoundland), 230, 232, 235.

3 There is no title page or cover, but the Inuktitut-German manuscript, dated 1780 in pencil on its first page, has the archival name "100 Lieder in Eskimo u[nd] Deutsch" [One-hundred Songs in Eskimo and German],” R.15.K.a..8, UAH.

4 The publication, printed in London by W. McDowall, numbered iv-277 pages and indicates on its title page: "Printed for the Brethren's Society for the Furtherance of / the Gospel; for the Use of the Christian Eskimaux in the /Brethren's Settlements, Nain, Okkak, and Hopedale, on / the Coast of Labrador." 
5 See the letter from Nain of 1 Sept. 1793, Periodical Accounts 1 (179095): 214.

6 See the letters from Okak from 1805 and 1806, ibid., 4 (1806-10): 79, 130, 133, 292-93, 295.

$7 \quad$ Letter from Okak of 23 Sept. 1807, ibid., 210.

8 See the letter from Okak of 1 Sept. 1809, ibid. 460-61.

9 TUKSIARUTSIT, / ATTOREKSET / ILLAGEKTUNNUT /

LABRADOREMETUNNUT. / Printed for the Brethren's Society for the Furtherance of / the Gospel; for the Use of the Christian Esquimaux in / the Brethren's Settlements Nain, Okkak, and Hope- / dale, on the Coast of Labrador (London: W. McDowall, 1824), 718 pp. See the letter from Okak, 24 Aug. 1825, Periodical Accounts 9 (1823-25): 376.

10 See the letter from Okak of 15 Aug. 1831, ibid., 12 (1831-34): 59.

11 Editorial addenda to a letter of Benjamin Gottlieb Kohlmeister, ibid., 9 (1823-25): 238. Benjamin Gottlieb Kohlmeister served congregations in Okak, Hopedale, and Nain until 1824, from 1819 on as Superintendent of the Labrador mission. See "Lebenslauf des verwitweten Bruders Benjamin Gottlieb Kohlmeister, heimgegangen zu Neusalz den 3. Juni 1844,” Nachrichten aus der Brüder-Gemeine 1849: 244-92.

12 [J.]P.[C.] Stock, J. Körner, and F.C. Fritsch, "Letter from Hopedale, September 9th, 1828," Periodical Accounts 10 (1826-28): 444. Johann Peter Christian Stock served churches in Hopedale, Nain, Okak, and Hebron before returning to Herrnhut, Saxony, in 1843, where he died in 1868. "Dienerblatt: Stock, Johann Peter Christian," UAH; "Moravian Registry: A. Eheleute und Witwer," no. 32, Moravian Church, Happy Valley, Labrador.

13 See the letter from Okak of 20 Aug. 1822, Periodical Accounts 8 (1821-23): 269-70.

14 "Journal entry, from Hopedale, 1826. Signed: [Johann] L[udwig] M[orhardt]," Periodical Accounts 10 (1826-28): 66-67. Johann Ludwig Morhardt, born 4 November 1782 in Okak, served the churches from 1814 and died after his return to Europe on 15 June 1854 in Herrnhut, Saxony. "Dienerblatt: Morhardt, Johann Ludwig," UAH; "Moravian Registry: A. Eheleute und Witwer," no. 33, Moravian Church, Happy Valley, Labrador; "Lebenslauf des am 15ten Juni 1854 selig 
entschafenen verheiratheten Bruders Johann Ludwig Morhardt," R.22.56.13, UAH.

15 Letter from Okak of 6 Sept. 1836, Periodical Accounts 14 (1836-38): 15.

16 See letter of Sister A.E. Kohlmeister from Nain, 11 Aug. 1821, ibid., 8 (1821-23): 182. "Extracts from Private Correspondence: From Nain," ibid., 13 (1834-35): 363.

17 "Extracts from Private Correspondence: From Nain," ibid., 14 (1836-38): 19.

18 Letter from Hopedale, 27 July 1837, ibid., 212.

19 Letter from Johannes Lundberg in Nain, ibid., 428.

20 "From Nain, 1830 [signed by L. Morhardt]," ibid., 11 (1829-30): 381-82.

21 “From Okak," 3 Aug. 1837, ibid., 14 (1836-38): 217. Christian Benedict Henn served in Hopedale, Nain, and Okak from 1819 to 1841 and was later a missionary in Suriname. He died in Amsterdam on 29 July 1845. "Dienerblatt: Henn, Christian Benedict," UAH; Church Book Hopedale (I), 8-9, Moravian Church Hopedale.

22 "From Nain, 1830 [signed by L. Morhardt]," Periodical Accounts 11 (1829-30): 381.

23 Christian Ignatius La Trobe, Letters to My Children; Written at Sea During a Voyage to the Cape of Good Hope, in 1815, edited and with an introduction by J.A. La Trobe (London: Seeleys, 1851), 40.

24 See the House Conference Letter from Okak from Aug. 1835, Periodical Accounts 13 (1834-36): 359.

25 See ibid., 16 (1841-43): 284. Johann Friedrich Martin served as missionary in Okak from 1841 to 1846 and died in Kleinwelka, Saxony, in 1854. "Moravian Registry: B. Ledige Brüder," no. 48, Moravian Church, Happy Valley, Labrador.

26 German: "Clavier." The term literally means "keyboard instrument," although today it is generally synonymous with "piano." By 1840 pianos were common in Europe, but they were expensive and, because they were cumbersome to transport, less likely to be carried from Europe than harpsichords, which were portable and abundant. The instrument referred to here is likely a harpsichord.

27 Sophia Sparmeyer (Sparmeier), born 2 April 1812, New-Herrnhut, St. Thomas, a teacher by profession, died on 26 March 1889 in Herrnhut, 
Saxony. (Moravian Registry, Happy Valley-Goose Bay, Labrador). See also "Lebenslauf des am 18. September 1867 in London selig entlafenen verheiratheten Bruders Carl Traugott August Freitag," Nachrichten aus der Brüder-Gemeine 1864, no. 4: 381-408.

28 On the pre-contact use of an Inuit fiddle (tautirit), see Maija M. Lutz, Musical Traditions of the Labrador Coast Inuit (Ottawa: National Museum of Canada, 1982), 12-13.

29 Jacobus, whose Inuktitut name was Tikkêtok, was likely the oldest son of Pappathina. He was baptized on 6 January 1808 by Brother Georg Schmidtmann in Okak. On 11 February 1815, he became a communicant. At one time, he seems to have been a chapel servant and organist, but in his final years was somewhat estranged from the congregation in Okak. He died on 6 April 1853 and - as customary at the time - was temporarily buried in the snow until a grave could be dug in the spring. See Church Book Okak, Adult Baptisms, no.75, 129; Communicants, no. 49, 178; Deaths, no. 392, 250 (Moravian Church, Labrador); German Diary of Okak, Jan.-Aug. 1853, 31-32, R.15. Kb.5.e, UAH.

30 German: "im Takt."

31 German: "Chorstücke."

32 This observation appears to be contradictory. The performance of anthems in three and four voices has been documented and is even noted by Freitag above. It may be that the choir in Okak was temporarily reduced at the time of this writing, but there is clear evidence of active four-voiced choirs in all Labrador stations since the 1820 s. Zacharias Glitsch came to Labrador in 1822 and served churches in Hopedale, Nain, Okak, and Hebron during his 25-year tenure in Labrador. See "Lebenslauf des am 28. Oktober 1857 in Herrnhut selig entschafenen verheiratheten Bruders Zacharias Glitsch,“; Nachrichten aus der Brüder-Gemeine, 1858: 322-37; Glitsch taught music already while in Nain. Periodical Accounts 9 (1823-25): 222. See also "From Hopedale," signed Z. Glitsch, ibid., 16 (1841-43): 525. 